\title{
¿Qué creen? No soy chismoso pero.... Mexican gossip: Affiliation or self-interest?
}

\author{
¿QUÉ CREEN? NO SOY CHISMOSO PERO.... \\ EL CHISME EN MÉXICO: ¿LA AFILIACIÓN O EL INTERÉS PROPIO?
}

\section{Gerrard Mugford}

Universidad de Guadalajara

\section{Resumen:}

Aunque hoy en día se analiza con más seriedad, sobre todo en las investigaciones antropológicas y sociológicas, el chisme sigue siendo considerado como trivial y de poco interés para los analistas del discurso. Tomando en cuenta que es imparable, persistente y a menudo agradable (Epstein 2011), el chisme ha sido examinado en términos de función (por ejemplo, hablar de temas íntimos para expresar valores compartidos) y como una forma de comunicación (por ejemplo, para expresar resistencia) (Goodman \& Ben- Ze'ev, 1994). En este capítulo, examino la importancia del chisme en el contexto mexicano.

En México, se ha estudiado el chisme en términos de función (Hagene 2010), situación (Vázquez García y Chávez Arellano 2008) y resistencia (Vázquez García 2007). En este estudio, se relaciona el chisme desde las perspectivas sociológico-antropológicas, psicológicas e individuales para identificar cómo los interactuantes utilizan el chisme para lograr la afiliación y autonomía.

Palabras clave: chisme; género; comunión fatico; afiliación; diversión

Abstract:

Whilst being taken more seriously, especially in anthropological and sociological studies, gossip is still often regarded trivial and of little academic research interest. Given that it is unstoppable, persistent and often enjoyable (Epstein, 2011), gossip has been examined in terms of function (e.g. talk about intimate 
matters to express shared values) and as a form of communication *for example, to express resistance (Goodman \& Ben-Ze'ev, 1994). In this chapter, I examine the importance of gossip in the Mexican context.

In Mexico, gossip has been examined in terms of function e.g. (Hagene, 2010), situation (Vázquez Garcia y Chávez Arellano, 2008) and resistance (Vázquez García 2007). I, however, study gossip from sociological-anthropological, social psychological and individual perspectives and evaluate how it is used to achieve affiliation and autonomy.

KEYWORDS: gossip; genre; phatic communion; affiliation; entertainment

\section{INTRODUCTION ${ }^{1}$}

Discursively and pragmatically, gossip has long been the subject of serious academic investigation in European and English-speaking academic contexts and especially in anthropological and sociological studies (Bergmann 1993: Jaworski \& Coupland, 2005; Tracy and Robles 2013). However, in the Mexican academic context gossip is still often regarded as trivial (Lopez Rodriguez, 2016) and does not merit any serious academic investigation. Given that it is unstoppable, persistent and often enjoyable (Epstein, 2011), gossip has been examined in terms of function (Bergmann 1993), genre (Thornbury and Slade 2006) and as a form of resistance and subversion (Goodman and Ben-Ze'ev, 1994). Given its pervasiveness in daily Mexican Spanish use, I want to understand how gossip is used in the Mexican context and whether it has own functions and its own characteristics. I will do this by contrasting its use in English where there may be a different understanding of the word 'gossip'.

In Mexican Spanish, gossip has primarily been examined in terms of social control (e.g. Hagene, 2010) and gender studies (e.g. Vázquez García 2007; Vázquez Garcia and Chávez Arellano, 2008, 2012). I will especially build on a productive approach pursued by Lopez Rodriguez (2013, 2016) who identifies Mexican gossip in terms of interaction and genre and hence attempts to identify its uniqueness and distinguishing features. Through a qualitative research using participant observation, I examine how interactants in Guadalajara, Mexico, realise interpersonal affiliation and autonomy through the use of gossip in Spanish. To achieve this, I examine data collected by ten informants and study the structure of gossip in Mexican Spanish, I argue that a conversation analysis approach highlights the interactional nature of gossip in developing, maintaining interpersonal relationships in terms of self-interest and group affiliation.

\footnotetext{
${ }^{1}$ This research was supported by the project «La atenuación pragmática en el español hablado: su variación diafásica y diatópica» (Ministerio de Economía y Competitividad de España, ref. FFI2013-40905-P).
} 


\section{DEFINING GOSSIP}

Whether examining definitions of gossip in English or Spanish, there seems to be little consensus regarding its characteristics. Such a lack of agreement to reach a common understanding is highlighted by Jaeger, Skleder, Rind and Rosnow who assert: 'Everyone seems to know what everyone else means by gossip, except the researchers who have wrestled with it as a technical term' (1994, p. 154). This observation suggests that one can identify two conceptualisations of gossip: first-order gossip (gossip1) and second-order gossip (gossip2) - similar to Eelen's (2001) distinction between first-order politeness and second-order politeness). Gossip1 reflects the layperson's everyday understanding of gossip whereas gossip2 is a theoretical abstraction.

\subsection{Gossip 1}

Gossip1, in Spanish, is reflected in openings such as Deja te cuento un chisme.... (Let me tell you a piece of gossip....), Te tengo un chisme.... (I have some gossip....), Te tengo que contar algo de.... (I have to tell you something), No le digas a nadie, pero me enteré de.... (Don't tell anyone, but I heard) and Fijate que... (Guess what). In English, Epstein (2011) identifies such openings as You mustn't tell anyone about this, but..., just between us .... and This must go no farther... A noticeable difference between Spanish and English is that gossips in Spanish will often use the word chisme (gossip) in their openings in contrast to English where the pretence at secrecy and discretion is frequently an overriding concern.

Gossip1 focuses on "news about the personal affairs of another" (Bergmann 1993, p. 45). Offering a German perspective, Bergmann argues that the content of gossip reflects communicative content e.g. spreading gossip and communicative process e.g. gossip as babble. Therefore, gossip can be seen as a commodity which has value and can be distributed - and even exchanged for other gossip. Focusing on an evaluative dimension, Noon and Delbridge offer the following working definition of gossip as "the process of informally communicating value-laden information about members of a social setting." (1993, p. 25). They see gossip as promoting judgemental positions among interactants. Whilst endorsing Noon and Delbridge's definition, Fox (2004) argues that their definition does not include celebrity gossip which takes up a significant amount of everyday social gossip time. Indeed Epstein differentiates between private or public gossip. Tracing the history of public gossip, Epstein notes that 'the best gossip ... wasn't about the family next door, but about the famous: royalty, the rich, politicians, successful artists, great athletes, and, in our time, movie stars' (2011, p. 75).

In Mexican Spanish, popular definitions have been offered by the Academia Mexicana de Lengua (AML) in Diccionario escolar de la AML (2015) developed by Moreno de Alba, Felipe Garrido and Mandujano Servín. They define gossip as habladuría and murmuración which appear to be synonymous words for gossip rather than definitions in their own right. More insightful is Moreno de Alba et al.'s definition of the verb chismear (to gossip) which they define

Normas (ISSN: 2174-7245) | 
as 'Contar cosas de otros sin tener pruebas de que sean verdad' (Tell things about others without having proof of their veracity) (Diccionario escolar de la AML). This Mexican Spanish definition introduces a moral dimension which appears to be missing from the everyday English-language understandings of gossip. In English, run-of-the-mill gossip reflects daily chitchat and newsworthy talk about local and celebrity subjects. Indeed Fox claims that the English spend two-thirds of conversation time engaged in gossip and that 'half of gossip time is taken up with discussion of the activities of the speaker or the immediate audience, rather than the doings of other people' (2004, p. 42). Furthermore, she claims that 'criticism and negative evaluations account for only about five percent of gossip time' $(2004,42)$. Therefore, there may be a significance difference about understandings of gossip between Englishlanguage and Mexican Spanish-language speakers.

In conclusion, on the layperson's level, there appear to be striking differences regarding what constitutes gossip in English and chisme In Mexican Spanish. English language usage focuses on the gossipy and newsy side of everyday chatter and hearsay during which gossips ask their listeners to keep the information to themselves. In contrast, Spanish-language gossips are more open about their activity whilst acknowledging that they are more likely to be talking about other people. Obviously, there are no strict dissimilarities between practices in English and Mexican Spanish are rather one of degree.

\subsection{Gossip2}

In trying to conceptualise gossip, social science researchers have looked at the phenomenon from the sociological-anthropological approach, the social psychological approach and the individual approach (Nevo, Nevo and Derech-Zehavi 1994, p. 181). Since these three approaches provide a wide variety of insights into the nature of gossip, I will use them to examine theoretical understandings of gossip.

The sociological approach envisages gossip in terms of how different speech and linguistic communities engage in gossip and its proponents examine the social functions of gossip. Nevo et al. argue that under this scheme '[g]ossip transmits information in order to teach and reinforce group norms. Gossip thus contributes to group cohesion, serves as a means to create stronger group identification, and helps to clarify group boundaries ...' (1994, p. 181). Therefore gossip can be seen as a way of reinforcing normative behaviour and maintaining a given group's values and attitudes.

Through the second approach, the social psychological perspective, research can examine the individual in relation to gossip as opposed to the group practices as proposed in the sociological approach. Nevo et al. argue that

Apart from the contribution of gossip to group norms and cohesion, it is important to remember that it is the individual who gossips. We must therefore consider what that individual gains from such behaviour. Social comparison, raised status, enhanced power, and entertainment are some of the results of gossip that have been highlighted by social psychologists. (1994 p. 181) 
Consequently, gossip may allow the individual interactant to pursue his or her personal communicative goals in order to satisfy his or her individual aspirations and needs.

The third approach, the individual standpoint, is focused on the creative dimension to gossip. Gossip may embrace 'illusions, dreams, jokes, and stories' as 'people project their own wishes, anxieties, and unconscious needs onto the objects of gossip.... Through it the individual can legitimately express aggressive and sexual fantasies or work on themes that arouse personal anxieties. Thus gossip serves as an adaptive defense mechanism' (Nevo et al. 1994: 182). Therefore gossip allows interactants to construct alternative realities and offer different ways of seeing and understanding the world.

These approaches allow researchers to understand gossip in terms of social control, social self-expression and individual creativity. This line of research helps to highlight differences in gossip practices between Mexican Spanish and British English.

Whilst the main thrust of this chapter is to examine gossip in sociological-anthropological, social psychological and individual terms, I will review the current literature on research which has been analysed in terms of genre and fantasy.

\section{GOSSIP AS GENRE}

Gossip as genre can be seen in negative and positive terms. The negative approach to genre has long seen it as reprehensible and immoral behaviour and should be avoided since it serves to undermine and criticise others. The positive viewpoint sees gossip as an important communicative resource that reinforces relationships and provides alternative ways of disseminating and receiving information (Goodman and Ben-Ze'ev, 1994).

A moral stance reflects the sociological-anthropological approach and perceives gossip as talking badly about a third absent person. Gossip is therefore a genre in its own right, being closely associated with rumour and scandal, which in Mexican Spanish is often discussed in detail, see for instance López Rodríguez $(2013,2016)$. In this approach, gossip is considered to be morally wrong. For instance, de Sousa says '[g]ossip, it is said, is often motivated by malice or envy; its enjoyment is often taken at the expense of others, whom it harms by exposing their vices and foibles to ridicule; and worst, it often sacrifices the truth' (1994, p. 26).

Mexican Spanish-language stances towards gossip often reinforce this view. For instance, the Diccionario del Español Usual en México defines gossip in moralistic terms:

\footnotetext{
Noticia o informe que se hace circular, bien sea verdadero o falso, sobre una persona, que puede enemistarla con otra o confundir a quienes lo reciben. "Me contaron el chisme de que Pepe y Lucha se pelaron", "Sabes el último chisme... ¡Se divorcian!", "Corre el chisme de un golpe de estado"

(Coloq) ir con el chisme Avisar o cantar a alguien alguna cosa para dañar a otra o causarle dificultades.

"¡Que fue con el chisme y el maestro nos castigó!

Andar, estar, etc. en el chisme (Coloq) dedicarse alguien a escuchar, espiar y averiguar alguna cosa:

"Marta se pasa el día en el chisme político
} 


\title{
Translation:
}

\author{
News or reports that circulate, whether true or false, about a person, who can make an enemy of another \\ or confuse those who receive it. "They told me the gossip that Pepe and Lucha were fighting," "You know \\ the latest gossip ... They are getting a divorce!", "Gossip is going around about a coup d'état." \\ (Colloquial) go with the gossip Warn or reveal to someone something aimed at harming the other or \\ causing difficulties. "He spread the gossip and the teacher punished us!" \\ To go with or to be gossiping, etc. (colloquial) to dedicate oneself to listen, to spy and to find out \\ something: "Marta spends the day in political gossip". \\ (Diccionario del Español Usual en México 2008: 316)
}

Such views echo Judeo-Christian attitudes towards gossip as its practice is frowned upon by the religious authorities. Within such a perspective, the use of gossip is seen to highlight deviant behaviour and its objective is to promote individual adherence to a given group's standards of behaviour, and especially religious norms of behaviour. A moral stance towards gossip sees gossip as serving no useful purpose and that it can even be dangerous as reinforced in the British government's World War Two propaganda poster: "Careless talk costs lives". The focus of this paper, however, is on the use of gossip as a social, interactive practice that helps establish, reinforce and maintain relationships.

\subsection{Gossip as a primary genre}

Identifying gossip as a communicative practice in its own right, Eggins and Slade (1997) and Thornbury and Slade (2006) examine gossip as a social practice which can be considered within the sociological-anthropological approach.

Through gossip, as Eggins and Slade point out, 'we build up and establish shared attitudes and identities, shared ways of seeing the world' (1997, p. 264). Even though the deviant person who is the subject of the gossip may not hear about his or her objectionable behaviour, those on the receiving end of gossip are called upon not only to admonish such improper behaviour but also to avoid engaging in it themselves.

\footnotetext{
Gossip ... involves sharing opinions and judgements about a person's behaviour or physical attributes, and by doing so implicitly asserting appropriate behaviour or defining a physical norm. In this way gossip reinforces and maintains the values of the social group. (Eggins and Slade 1997, p. 276)
}

As a genre in its own right, gossip covers a host of communicative practices since 'it can refer to any "idle" chat about daily life; it can, on the other hand, be used to characterise women's talk in general (and therefore sometimes used as a sexist put-down of such talk), or it can be used more specifically to refer to conversations between two or more people about another person behind his/her back' (Eggins and Slade 1997. p. 278). 
Therefore gossip needs to be seen on a continuum which ranges from casual everyday chatty conversation along to its more serious normative functions of trying to undermine other interactants.

At the casual end of the continuum, Epstein rejects the solely morally harmful nature of gossip and argues that

[n]ot all gossip is engaged in for the purpose of hurting people. Gossip can be wildly entertaining. Sometimes analyzing the problems, flaws, and weaknesses of friends, even dear friends, sweeps one up and carries one away in sheer exuberance for the game. (2011, p. 8)

Epstein's observation reflects the enjoyable dimension to gossip which contains no underlying malicious intent towards the object of the chatter. Dunbar sees gossip in the context of interactants' mutual interest in each other's comings and goings:

What characterizes the social lives of humans is the intense interest we show in each other's doings. We spend literally hours in each other's company stroking, touching, talking, murmuring, being attentive to every detail of who is doing what with whom. (1996, p. 9)

Therefore, gossip needs to be seen in terms of bonding, grooming and developing relationships with others as 'we use language daily to try to influence the lives of those around us, ultimately for our own benefit' (Dunbar 1996, p. 171). Dunbar even goes as far as to say that 'language evolved to allow us to gossip' (1996, p. 79). Within this scheme gossip is not focused on criticising others but on reinforcing and developing social relationships.

Towards the middle of the continuum, gossip can be positioned on a par with everyday conversation:

Gossip is a highly interactive genre: participants frequently co-construct the gossip, recipients provide continual feedback to indicate interest (and complicitness with the gossip) or ask questions to elicit more details. (Eggins and Slade 1997, p. 276)

This viewpoint questions the traditional sender-receiver view of communication (Shannon and Weaver's 'source-encoder-channel-decoder-destination' archetype as in Sperber and Wilson 1995, p. 4) and sees gossip as being co-constructed. As sawyer argues: 'If someone suddenly looks confused, we notice and then pause a second to clarify what we just said' (Sawyer 2001, p. 187). Furthermore, the gossip needs to be given a ticket (Goffman 1974, p. 508) authorisation by other participants for an interactant to engage in an extended turn. This is because 'the sharing of an opinion about an absent third person (often a friend) is potentially face-threatening and therefore there needs to be explicit or tacit approval given for the gossip to proceed' (Eggins and Slade 1997, p. 277). The gossip and his/her addressee are colluding secretly and this may explain some of the excitement that gossip can give to both speaker and addressee as they engage in illicit behaviour. Furthermore, the addressee may have achieved, albeit temporarily, the status of a privileged insider. This may lead to a 'them' and 'us' situation that is reinforced through gossip: 'The social purpose of gossip, i.e. the creating and maintaining of group solidarity, is reflected in the choice of language used, particularly in the 
way that group membership is indexed by invoking a them vs. us polarity. (Thornbury \& Slade 2006: 176).

The 'them' and 'us' dimension to gossip indicates that its practice not only reinforces and strengthens relationships but helps identify social boundaries that exclude others and even warns interactants who they need to be wary of.

\title{
3.2 Gossip as a sub-genre
}

An alternative view sees gossip as a normal every day, and perhaps necessary, social practice as individuals position themselves with respect to others. Analysable within a social psychological framework, the individual actively decides how she or he wants to come across.

Gossip as social and individual practice was highlighted by Malinowski who related gossip to phatic communion and small talk. Even though his reference to 'savages' instead of 'indigenous people' is insulting and demeaning in present day discourse, his understanding regarding the use of gossip is nevertheless important:

\footnotetext{
... in pure sociabilities and gossip we use language exactly as savages do and our talk becomes "phatic communion" ... which serves to establish bonds of person union between people brought together by the mere need of companionship and does not serve any purpose of communicating ideas. (1923/1969, p. $315-316)$
}

Far from morally condemning gossip, Malinowski positions gossip within the genre of small talk since it provides an interpersonal resource with which to interact with others.

Whilst Malinowski offered no concrete examples of his observations, his argument has subsequently been pursued by Blum-Kulka (2000), Eggins and Slade (1997), and Jaworski (2000). Jaworski specifically locates gossip with small talk:

\begin{abstract}
There are many approaches to defining small talk, this is certainly true of most other concepts in sociolinguistics and other academic disciplines, although, of course, some concepts are more established and more widely accepted than others. It seems, however, that our definitional dilemmas are most easily overcome if we apply specific terminology of the near synonyms such as small talk, phatic communion, chit-chat-chat, gossip, casual conversation and the like to specific communicative situations. The everyday understanding of these terms allows for a considerable overlap among them, yet we have no difficulty in choosing one or the other to label a particular stretch of (sociable) talk. (Jaworski 2000, p. 111)
\end{abstract}

Therefore, Jaworski sees gossip as a fuzzy concept since it does not neatly fit into a watertight category. Furthermore he says: '[w] could argue that gossip during a coffee break in an office is a form of small talk, while enquiries about one family members' health in an opening of a conversation is also talk "about" relationships. But to dwell on precise delimitation of boundaries between such terms is futile' (Jaworski 2000, p. 112). It is perhaps more useful is to examine gossip from a social psychological perspective as participants interact with others and project their individuality. 
Blum-Kulka (2000) argues that in a given text there is no inherent 'meaning in the content of communications about others' (2000, p. 213). Specifically referring to gossip and focusing on the use of gossip within family conversation, Blum-Kulka argues that 'in studying forms of talk about others in the family what is striking is the degree of fluctuation in the nature of the talk: sometimes it is felt (to its distant observers listening to it later) to be the light, idle talk 'happy conversations' .... at other instances one is struck with the gravity of the underlying moral issues at stake. Yet as in all narrative events in the family, it occasions the negotiation of personal, familial and cultural identities (Blum-Kulka 1997) ....' (Blum-Kulka 2000, p. 213).

At the same time, Blum-Kulka notes that gossip does not have to be goal-oriented: 'In the family truly idle talk seems to emerge only under conditions of low emotional involvement, as in the case of celebrity talk, while in all other gossip narration it is underscored by issues of personal, familial and cultural identity' (Blum-Kulka 2000, p. 214). Therefore, gossip reflects individual interest in, and involvement concerning, the topic or person being discussed.

Building on the work on Malinowski, Bergmann argues that gossip is omnipresent in everyday social discourse being 'a concept from daily life. (1993, p. 19). At the same time, Bergmann argues that gossip is not inherent in a given utterance or text but needs to be constructed and agreed upon: 'If we start from the plausible assumption that not every conversation is gossip, then we must assume that our partners have the capacity to evoke gossip as an autonomous, intersubjectively shared form of communication, which implies the capacity to decide from individual indicators when a conversation is gossip or turns into it' (Bergmann 1993, p. 20 21). This stance reinforces the individual dimension to gossip as participants need to identify it as gossip and construct it as such: 'gossip thematizes social events that are past events for the participants and therefore must be reconstructed. But the communication of gossip is itself a social event that, with its occurrence, becomes part of the past and thereby forces the social researcher who investigates gossip to reconstruct it' (Bergmann 1993: 35). Furthermore "Gossip emerges as "gossip" through the performance of actions that are distinguished, perceived, and answered by the participants specifically as acts of gossip in the concrete action situations'.

This stance would suggest that gossip cannot be automatically designated as a genre. Gossip needs to be agreed upon as it emerges from interactants working together in its development.

\subsection{Fantasy gossip}

From the individual standpoint, gossip can reflect creative language use at both group and individual levels. Sawyer asserts that 'researchers have found that gossip is some of the most creative conversation' (2001, p. 187). Creative language use involves playing with grammatical structures, engaging in repetition and extending meaning as interactants express their attitudes, values, perceptions and experiences about people and events. In doing so, participants may create an alternative reality. 
Cook argues gossip belongs to that category of language use that interactants find 'most interesting' (2000, p. 68). Building on the work on Dunbar (1996), Cook argues that gossip (along with playful talk) 'may regulate and maintain relationships' and therefore

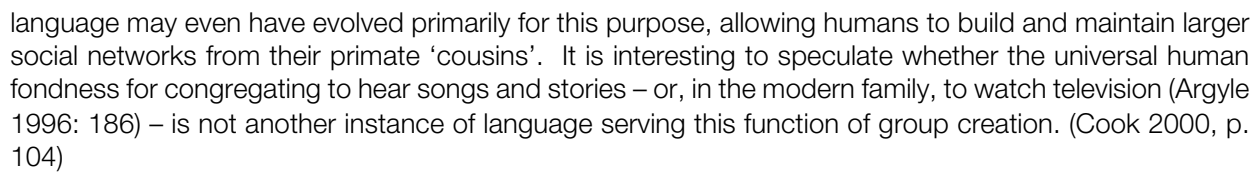

Free from the restrictions of transactional language use, gossip and language play give interactants a free range regarding how what to talk (or write) about and who they select. There are few limitations on how they discuss and present the person being gossiped about:

It is not the language emanating from work which attracts people when they are free to choose, but that of songs, games, fictions, gossip, humour, aggression, intimate relations, and religion. Indeed, publishers' lists of what should not go into a language teaching textbook could be read as recommendations for what should go into a bestselling novel, lead news story, or blockbuster TV series. (Cook 2000: 159)

\section{MEXICAN PERSPECTIVES ON GOSSIP}

As argued by López Rodríguez $(2013,2016)$ and Vázquez García and Chávez Arellano (2008), research into gossip within the Mexican context has been limited. However, research can be understood in terms of sociological-anthropological and the social psychological. In Mexican Spanish, the creativity dimension with respect to gossip does not appear to have been the subject of research.

In discussing the structure of gossip in Zinacantán, southern Mexico, Haviland (1977) emphasises the co-operative and narrative nature of gossip. Structurally gossip can be analysed in terms of the identification of subjects, storyline and evaluation and this reflects a sociological-anthropological dimension. The gossip generally moves to a moral evaluation as the subject of his or her gossip is seen as breaking a " cultural rule", (or "norm" or "value")' (1977, p. 57). However, this evaluation is not simply about "the "rules" that purportedly "govern" behavior' (1977, p. 58). Appropriate behaviour needs to be 'worked out, even invented and manipulated through the course of elaborate conversations' (Rosaldo 1978, p. 687). Therefore gossip reflects dynamic interaction as appropriate behaviour is identified and agreed upon before any evaluation can take place.

Gossip and gender are the subjects of considerable interest among researchers in Mexico (Vázquez García 2007; Vázquez García and Chávez Arellano 2008; 2012). Examining the role of gossip as a control mechanism and whether there are forms of resistance to gossip, these studies often reflect a social psychological focus. For instance, investigating gossip at the Universidad Autónoma Chapingo, Texcoco, in the State of Mexico Vázquez García and Chávez Arellano (2008) argue that 'el chisme es un vehículo a través del cual se expresa el poder, entendido en este contexto como las distintas normas que regulan la sexualidad femenina y masculina' (2008, p. 86) ('Gossip is a vehicle through which power is expressed, understood 
in this context as the different norms that regulate female and male sexuality'). At the same time, Vázquez García and Chávez Arellano (2012) also examine gossip, sexuality and hegemonic masculinity at the Universidad Autónoma Chapingo where they conclude: 'Gossip was conceived as a discursive device that serves several functions: it strengthens the social identity of a particular group of people, it reinforces norms by exhibiting the punishment that some people face when not abiding by such norms, when ill-intentioned gossip helps the speaker to promote his or her own interests and gain symbolic capital' (2012, p. 175). As López Rodríguez (2016) notes, Vázquez García and Chávez Arellano undermine the common perception that women gossip more than men. Vázquez García and Chávez Arellano emphasise both the sociological-anthropological and the social psychological aspects of gossip which indicates that it is not always easy to differentiate between these two modes of analysis.

Whilst not directly related to social gossip, Hagene (2010) focuses on gossip and political practice. She examines political gossip as both social and more formalised control. Examining practices in the town of Alcopilco near Mexico City, Hagene concludes that it is not always easy to see gossip as a form of social control since a multitude of other factors need to be taken into consideration especially if the gossips themselves actually take part in morally wrong behaviour and thus making it harder to condemn such practice.

Arguing for the importance of studying gossip from anthropological, sociological and psychological aspects, López Rodríguez, in her review of relevant literature in the Mexican context, concludes that: 'Chismear implica compartir opiniones y juicios acerca del comportamiento de una persona, sus atributos físicos y hacer afirmaciones implícitas de lo apropiado o normal'('Gossip involves sharing opinions and judgements about a person's behavior, their physical attributes and making implicit assertions about what is appropriate or normal)' (2016, p. 15). Therefore her review identifies sociological-anthropological approach in Mexican research on gossip.

Whilst gossip in Mexico has been researched in terms of sociological-anthropological and the social psychological aspects, no research was uncovered regarding gossip in its individual dimension. As a conclusion, the research that has been undertaken has focused on the function of gossip as social control.

\section{Methodology}

As argued by Bergmann (1993) and Haviland (1977) to access the empirical field of gossip, researchers need to actually participate in the activity. Gossip cannot be observed and analysed at a distance because gossip is shared and co-constructed by an insider group. Following this line of argument, the research methodology in this chapter reflects a quantitative participant observation approach as the 'gossip' informants generally interacted with peers within their own social context. 
The theoretical field in this research aims to identify the characteristics and functions of gossip in various social contexts in Guadalajara, Mexico. Given the unpredictability of anticipating gossip, observers looked for an 'opportunity sample' (Brown \& Dowling 1998, p. 29) where gossip was seen to emerge. Whilst most opportunities arose within daily social interaction, some examples emerged on the streets as passers-by engaged in gossip.

This research aims to answer the following overarching question: How do Mexican Spanish interactants engage in social gossip in Guadalajara, Mexico? Given the substantial literature on the structure and function of gossip in English, this chapter tries to identify Spanish-language gossip patterns and practices in Mexico. To do so, the specific research question are

1. What are the interactional practices that characterise social gossip in Mexican Spanish in Guadalajara, Mexico?

2. How do Mexican Spanish-speaking interactants engage in creative language use when engaging in gossip?

To answer the overall and specific research questions, I will examine gossip practices by reviewing the applicability of the sociological-anthropological, the social psychological and the individual approaches.

In the local empirical setting data was collected through participant observation by 12 participants from a public university in Guadalajara. Aged between 18 and 22 and from middleclass backgrounds, the participant-observers attempted to record instances in which they were not closely involved and noted the interaction through 'reconstructed dialogues' i.e. writing down the events as soon as possible afterwards. Typical events included social interaction at parties, conversations in cafés and restaurants and public talk on public transport and in the street. The total corpus amounted to 36 interactions of varying length from five to fifteen minutes.

\subsection{Data}

In analysing data in terms from the sociological-anthropological, the social psychological and the individual perspectives, a reduced number of examples will be given for reasons of space but hopefully they will fully illustrate the features and characteristics of Mexican gossip.

\subsubsection{Sociological-anthropological approach}

The focus of sociological-anthropological approach on highlighting group norms can be seen in numerous examples from the corpus.

Moral condemnation was a common feature of this category of gossip as can be seen in the following example. 


\section{Example 1:}

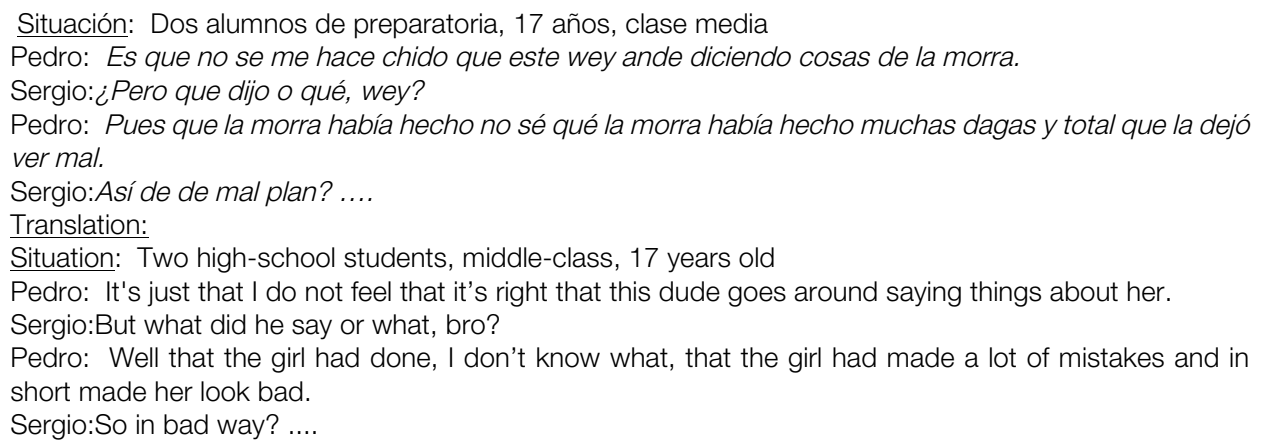

The two interactants adopt a disapproving attitude to 'this dude' who is disparaging a girl: Pedro appears to be condemnatory as Sergio is supportive of his stance. First of all, Pedro seeks support as he makes the statement: It's just that I do not feel that it's right that this dude goes around saying things about her. Pedro does not immediately demonstrate outright support as such but seeks extra information with But what did he say or what, bro? Rather than stating what 'this dude' might have said, Pedro unconditionally defends the girl and her image instead providing any details. This stance produces implicit support from Sergio who with his question: So in bad way? .... appears to be asking for examples of unacceptable behaviour. Whilst the conversation shows gossip being used to adopt a moral position, the focus is on defending a third party rather than providing details. This can be seen as solidarity gossip - protecting one interactant against another without providing evidence.

In the second example, a friend is telling another friend about how her mother reacted to her quitting her job. She appears to seeking moral support regarding the decision she has made.

\section{Example 2:}

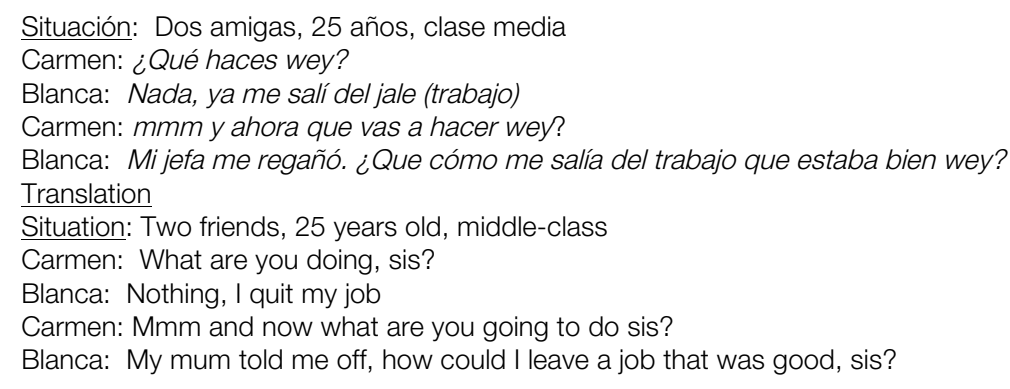

After Carmen asks a simple question, What are you doing, sis?, Blanca engages in selfdisclosure as she reveals not only has she quit her job but her mother is extremely annoyed. Whilst Carmen did not reveal her stance towards Blanca's news, the example shows how selfdisclosure may be an important dimension in gossip as interactants seek understanding and support regarding decisions that they have taken. 


\subsubsection{Social psychological approach}

The social psychological approach reflects the social interest dimension behind gossip and often its entertainment value. In the two following examples, social interest and personal speculation characterise the gossip.

In the third example, the conveyer of gossip is seeking direct support in her evaluation regarding the actions of somebody they both know:

\section{Example 3:}

Situación: Dos amigas, universitarias, 20 y 22 años, clase media Ana:No manches wey ¿qué crees que me dijeron?

Carla: $A$ ver wey, ¿qué?

Ana:Pues ¿te acuerdas de Rafa?

Carla:Si, ¿por qué?, ¿qué pasó?

Ana: Pues haz de cuenta que su amigo Javier me contó que el otro día fueron a jugar futbol, y que Rafa se llevó a una "amiga" a verlo jugar y pues obvio que no era Cinthya (su novia) era otra chava y que estaban muy abrazados y todo, ¿cómo ves?

Carla: Y no manches pues q mal plan para Cinthya, y ¿crees q ella sepa?

Ana:No wey, ella de seguro no sabe nada

Carla: Oh pues que mal plan por parte de ese wey

Ana:Pues sí pero pues igual es su problema ja ja

Carla:Sí ja ja ni para qué meternos en eso

Translation:

Situation: Two friends, university students, 20 and 22 years old, middle-class

Ana: No dude no way. What do you think they told me?

Carla:Let's see, sis, what?

Ana:Well, do you remember Rafa?

Carla:Yes, why? What happened?

Ana: Then imagine that his friend Javier told me that the other day they went to play soccer, and that

Rafa took a "friend" to see him play and then obviously she was not Cynthia (his girlfriend) it was another girl and they were hugging and everything, what do you think?

Carla: And no way then what a bad situation for Cynthia, and do you think she knows?

Ana:No sis, she sure knows nothing

Carla:Oh, in what bad way that dude is carrying on

Ana: Well yes but then it is his problem ha ha

Carla:yes ha ha it is not for us to get involved in that

Ana appears to be repeating gossip that she has been told with: what do you think they told me?. They quickly establish who the subject of the gossip is, Rafa, and the source of the gossip is Javier. Ana says that Rafa did not take his regular girlfriend to the soccer match and that he was being intimate with this new friend. Carla helps to co-construct the gossip by seeking information about whether the girlfriend knows about the situation. Saying that girlfriend knows nothing, Ana seems to distance herself from taking any action saying that his problem. The gossip does reflect moral condemnation and reveals an unwillingness to take any action. Gossip reflects 'chatty' news rather than moral judgement. 
Example four underlines how gossip does not have to involve talking disparagingly about another but rather in helping one another out.

\section{Example 4:}

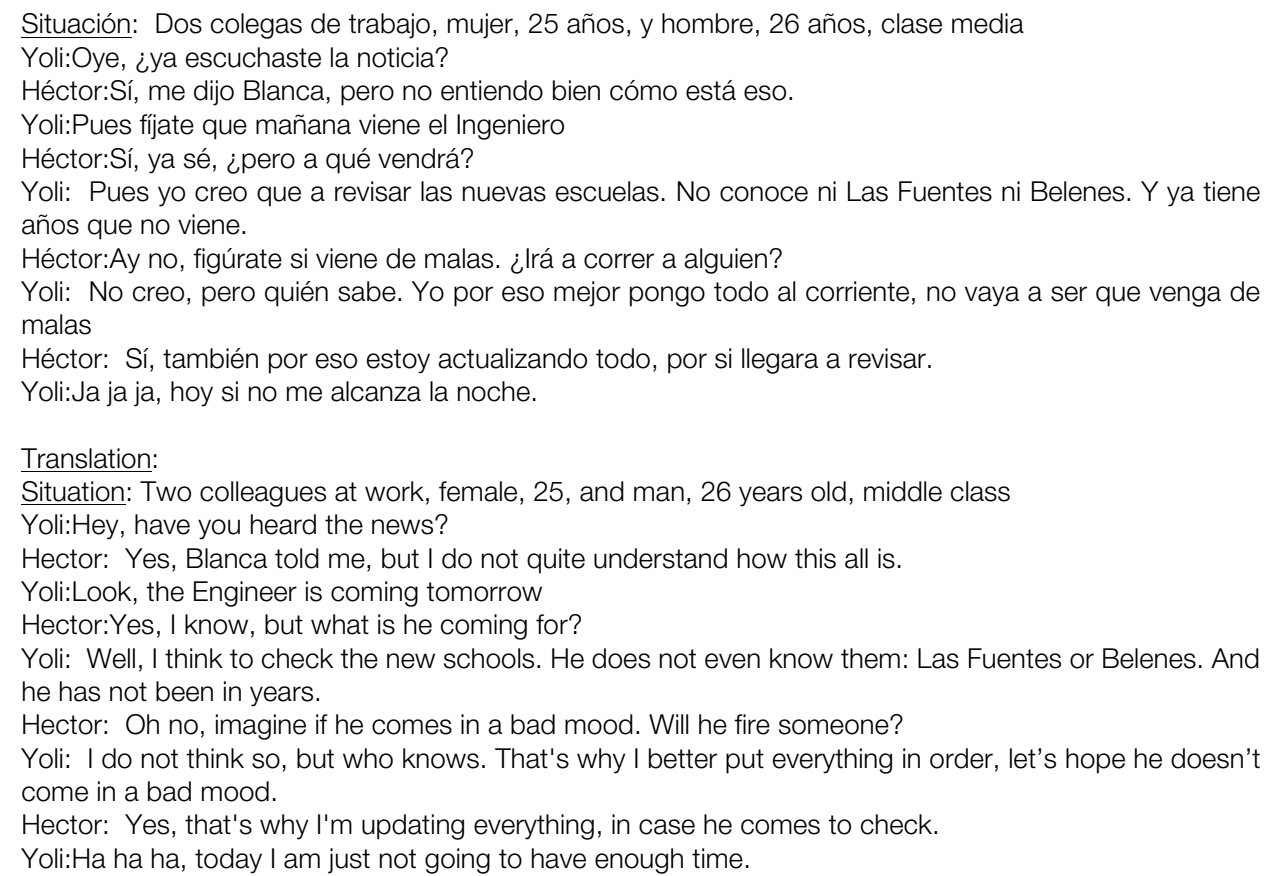

In this example, gossip concerns forewarning a colleague and speculating about the actions of a third party. Gossip comes from Blanca, who apparently is forewarning her work colleagues that their boss, el ingeniero (literally meaning 'the engineer' but, in Mexico, used to refer to a person's professional title). The gossip speculates on the reason for his visit: I think to check the new schools (located at Las Fuentes or Belenes). Given the tenure of the conversation, the interactants are more worried about the ingeniero's mood rather than their work performance as they ask imagine if he comes in a bad mood. Will he fire someone? and I do not think so, but who knows. The gossip gives both interactants time to take precautionary measures.

\subsubsection{Individual approach}

The individual approach reflects how gossip may be used to fantasise and engage in creative language use. In the two following examples, interactants speculate about a woman's breast size and also about romantic disappointment.

In example 5, three woman are chatting about another woman's breast size. 


\section{Example 5:}

Situación: Tres mujeres, 30 años, clase media, en la calle observando otra mujer

Denise: ¡iMas de 50!! Pues ¿Que hacen? ¿Se inflan solas? =

Estefanía:(risa leve) no

Denise: Pero pérate dijeras se los puso (haciendo seña de tamaño grande en su pecho) acá no en tamaño big size! pero no era una cosa así término...

Griselda: normal

Estefanía:bueno es que si estaba así como más como... Sofía. Término una cosa, no menos que Tere... un término medio pero... ¿50 baros?! ¿Tú pagarías eso?

Denise: ¡No!

Estefanía:Por quedar casi igual pero con un poquito más. jajaja

Griselda: No, una amiga mía si se las puso y al principio ni siquiera se ponía blusas...escotadas de que le daba como... pues se ha de haber sentido rara.

Estefanía: ¡Qué albur!

Translation:

Situation: Three women in their thirties. Middle class, observing another woman

Denise: Over 50!! Well, what do they do? Do they inflate on their own?

Estefanía: (slight laugh) no

Denise: But wait you said they put them (using a gesture to show the big size of breasts) up like this not a big size! But it was not something like that....

Griselda: Normal

Estefanía: Well, it is if it was like that, it would be more like.... Sofia. Finished one thing, not less than Tere ... somewhere in between but ... 50 pesos?! You would pay for that?

Denise:

Estefanía: For being almost the same but with a little more. Hahaha

Griselda: No, a friend of mine yes she had it done and at the beginning did not even wear blouses ... low cut so to give them like ... but she must have felt strange.

Estefania: What a double entendre!

Denise starts off the conversation by speculating about bust size of a woman passing by. Subsequently the conversation descends into light-hearted speculation as they engage in insider's language: the women use English i.e. big size! and expressions such as 'finished'. Estefania finally reveals that they were talking in a double sense with her What a double entendre!

In example 6, the interactants reflect on the popularity of a girl among the boys whilst revealing her religious orientation:

\section{Example 6:}

Situación: Dos amigas, universitarias, 23 y 25 años, clase media

Julieta: ¿Gloria? ¿La que conocí la otra vez en la fiesta?

Raquel: Sí, ella, ella.

Julieta:;Ah! ¡No manches!

Raquel: La que se le aventaron como un montón de batos.

Julieta: ¡No ma...!Tan buena onda que es, tan bonita ella. ¿Y qué hizo?

Raquel: No, no, no, pos nomás les puso en la foto les puso un comentario nomás diciéndoles: "Qué

Dios los llene de bendiciones" y ya pues porque ella es muy cercana a Dios y pues no.

Julieta:Pero ...

Translation.

Situation: Two friends, university students, 20 and 22 years old, middle-class

Julieta:Gloria? The one I met the other time at the party? 
Raquel: Yes, she, she.

Julieta:Ahhhhh! Really!

Raquel: The one that got a lot of proposals

Julieta: Really ...! So cool she is, so pretty. And what did she do?

Raquel: No, no, no, she just put the following comment in the photo: "May God bless you all" and then because she is very close to God and well no

Julieta:But ...

The two girls are talking about Gloria - a girl that Julieta had met at a party. Raquel confirms her identity by saying The one that got a lot of proposals. Julieta expresses admiration for her and then reveals that Gloria's interests lie elsewhere and that she is a very religious person. It reflects gossip which has denouement and even a 'punchline' and can be categorised as 'narrative gossip' as Gloria posted "May God bless you all".

The data reveals that gossip is not just focused on passing moral judgment on others but rather that there are a wide range of communicative objectives that often focus on the gossips themselves. Furthermore, it appears that gossip is not engaged in for its own sake but to achieve much more concrete objectives.

\section{ANALYSIS AND DISCUSSION}

This discussion section focuses on how sociological-anthropological, social psychological and individual perspectives help develop an understanding of gossip practices in the Guadalajara, Mexico.

The sociological-anthropological perspective is apparent in examples 1 and 2 which reflect moral condemnation. This categorisation reflects conventional attitudes towards social gossip. In example 1, the interactants engage in 'solidarity gossip' as they unreservedly defend the victim, an unnamed girl, rather than on detailing the actions of the 'dude' who is belittling her. In example 2, the conversation shows how gossip about oneself and a third party may involve 'self-disclosure gossip' as one participant attempts to gain supportiveness and/or solidarity from another. There appears to be an implicit acceptance that the gossip acted wrongly and there is no attempt on her part to justify or defend her actions in leaving her job. This example demonstrates that gossip does not only have to be about a third party but can involve the gossip himself or herself.

The social psychological view that can be detected in examples 3 and 4 which reflect social interest in terms of entertainment, speculation and solidarity rather than any moral condemnation. In Example 3, the thread of the gossip highlights wrongful behaviour by the subject of the gossip by bringing a girl who is not his girlfriend to a soccer match but that is as far as it goes. There is no attempt to undertake any action that would 'punish' the subject who is behaving badly i.e. who is being unfaithful to adhere to group norms. The interactants view the gossip in entertainment and moralistic terms and say they will not interfere. They condemn the subject's attitude but they do not dare to interfere because it may be a little dangerous or risky. 
In Example 4, gossip concerns forewarning a colleague about an impending visit and speculating about the actions of a third party. By engaging in 'speculative gossip', both interactants are worried about their future status and show no interest in condemning the actions of a third party. Therefore gossip can be speculative in examining people's motives rather than in demeaning them.

The individual perspective is reflected in examples 5 and example 6

Example 5 reflects a secretive use of language that contains a double meaning as the interactants discuss bust size with getting into specific details. The interactants engage in fantasy gossip as they speculate on whether they would have such an operation done on themselves. This is another example of gossip in terms of entertainment and amusement.

In example 6, the interactants contrast two aspects of the subject of the gossip: the girl who is popular among boys and the same girl who is devoted to God. This takes gossip to the level of surmising and conjecture but has no harmful intention behind it.

In summary, it is an oversimplification to see gossip as solely condemnatory talk about a third party where interactants are trying to uphold and perhaps even enforce moral norms. As seen in these examples, gossip gives interactants a way to discuss how they experience the world and convey those experiences to others.

\section{CONCLUSION}

This brief and limited analysis indicates that, whilst gossip can be labelled in terms of sociological-anthropological, social psychological and individual perspectives, it is possible to identify unique features of gossip. These have been detected in terms of 'solidarity gossip', 'self-disclosure gossip', 'entertainment gossip' and 'speculative gossip' and 'fantasy gossip'.

In this chapter I have answered the research question How do Mexican Spanish interactants engage in social gossip in Guadalajara, Mexico? By arguing that the gossip does not only reflect sociological-anthropological, the social psychological and the individual perspectives but also that they reflect very specific objectives and patterns of use. These interactional practices have been characterised in terms of solidarity gossip, self-disclosure gossip etc.

I have added to an overall understanding of Mexican gossip patterns and practices by identifying gossip as creative language use which has not been the subject of research in Mexican Spanish.

Whilst the number of examples are limited and only reflect the practices in one Mexican city, the results suggest that gossip needs to be studied more extensively in the Mexican context with the aim of further developing the characteristics, objectives and functions of Mexican Spanish-language gossip. 


\section{REFERENCES}

ARGYLE, Michael (1996): The Social Psychology of Leisure, Harmondsworth: Penguin.

BERGMANN, Jörg R (1993): Discreet Indiscretions: The Social Organization of Gossip, New Brunswick/London: Aldiner Transaction.

BLUM-KULKA, Shoshana (1997): Dinner Talk: Cultural Patterns of Sociability and Socialization in Family Discourse, Mahwah, New Jersey: Lawrence Erlbaum.

BLUM-KULKA, Shoshana (2000): Gossip events at family dinner: negotiating sociability, presence and the moral order. In Coupland J. (ed.) 2000, Small Talk (pp. 211 - 240), Harlow, Essex: Pearson.

BROWN, Andrew and Paul DOWLING (1998): Doing Research / Reading Research: A Mode of Interrogation for Education, London: Falmer.

COOK, Guy (2000): Language Play, Language Learning, Oxford: Oxford University Press.

DE SOUSA, Ronald (1994): In Praise of Gossip: Indiscretion as a Saintly Virtue. In Goodman, Robert \& Aaron Ben-Ze'ev (eds.)(1994): Good gossip. (pp. 25 - 33) Lawrence, KS: University Press of Kansas

Diccionario del Español Usual en México 2008. México: Colegio de México.

DUNBAR Robin (1996): Grooming, Gossip, and the Evolution of Language, Cambridge, Massachusetts: Harvard University Press

EELEN Gino. (2001): A Critique of Politeness Theories, Manchester: St. Jerome.

EGGINS, Suzanne \& Diana SLADE (1997): Analysing casual conversation, Londres, Cassell.

EPSTEIN, Joseph (2011): Gossip, New York: Houghton Mifflin Harcourt.

GOODMAN, Robert and Aaron BEN-ZE'EV (eds.)(1994): Good gossip. Lawrence, KS: University Press of Kansas.

FOX, Kate (2004): Watching the English: The hidden rules of English behaviour, Hodder: London

GOFFMAN Erving (1974): Frame Analysis: An Essay on the Organization of Experience, Boston: Northeastern University Press.

HAGENE, Turid (2010): Prácticas políticas cotidianas en un pueblo originario del Distrito Federal: el papel de los chismes y rumores. Nueva antropol [online]. 2010, vol.23, n.73, pp. 35 - 57. Consultado 30/11/2016 http://www.scielo.org.mx/pdf/na/v23n73/v23n73a3. pdf

HAVILAND, John (1977): Gossip, Reputation and Knowledge in Zinacantan, Chicago, The Chicago Press.

JAEGER, Marianne, Anne A. SKLEDER, Bruce RIND and Ralph ROSNOW (1994). Gossip, Gossipers, Gossipees. In Goodman, Robert F. \& Aaron BenZe'ev (eds.). Good gossip (pp. 154 - 168). Lawrence, Kansas: University Press of Kansas.

JAWORSKI, Adam (2000), Silence and small talk. In Coupland J. (ed.) Small Talk, (pp. 110 - 132) Harlow, Essex: Pearson.

JAWORSKI, Adam, and Justine COUPLAND (2005): Othering in gossip: 'you go out you have a laugh and you can pull yeah okay but like...'. Language in Society 34: 667 - 694.

LÓPEZ RODRÍGUEZ, Fabiola (2013): El chisme como género de la conversación casual: estrategias discursivas y posicionamientos en el contexto de una red personal, universidad de Guadalajara: MA Thesis

LÓPEZ RODRíGUEZ, Fabiola. (2016): Antecedentes teóricos del chisme. In Insights in the Research of English, Nahuatl and Spanish Languages and Cultures in Mexico, Guadalajara: Universidad de Guadalajara.

MALINOWSKI Bronislaw (1923)(1969), The Problem of Meaning in Primitive Languages in Ogden C.K. and I. A. Richards, The Meaning of Meaning: $A$ Study of the Influence upon Thought and of The Science of Symbolism, London: Routledge \& Kegan Paul Ltd.

MORENO de ALBA, José G., Felipe GARRIDO y Rocío MANUJANO SERVIN (2015): Diccionario escolar de la http://www.academia.org.mx/universo:lema/obra:Di ccionario-escolar-de-la-AML consulted November 14, 2016

NEVO Ofra, Baruch NEVO and Anat DERECHZEHAVI (1984): The Tendency to Gossip as a Psychological Disposition: Constructing a Measure and Validating It. In Goodman, Robert F. \& Aaron Ben-Ze'ev (eds.). Good gossip (pp. 180 - 189). Lawrence, Kansas: University Press of Kansas.

NOON, Mike and Rick DELBRIDGE (1993): News from behind my hand: gossip in organizations, Organization Studies, Winter, 1993, Vol.14(1), p.23. 
Real Academia Española 2001 Chisme, en Diccionario de la lengua española (22.a ed.), < http://lema.rae.es/drae/>, visitada el 30/12/2016

ROSALDO, Renato (1979): Review of Gossip, Reputation, and Knowledge in Zinacantan by John Haviland. Man 13: 686 - 687.

SAWYER, R. KEITH (2001): Creating Conversations: Improvisation in Everyday Discourse, Cresskill, $\mathrm{NJ}$ : Hampton Press.

SPERBER, Dan and Deirdre WILSON (1995): Relevance: Communication \& Cognition, Oxford: Blackwell.

THORNBURY, Scott and Diana SLADE (2006): Conversation: From description to pedagogy, Cambridge: Cambridge University Press.

TRACY Karen and Jessica ROBLES (2013): Everyday Talk: Building and Reflecting Identities, New York: Guildford Press.
VÁZQUEZ GARCIA, Verónica (2007): El chisme y la violencia de género. En búsqueda de vínculos. En Roberto Castro e Irene Casique, (editores) Estudios sobre cultura, género y violencia contra las mujeres (139 - 172). Cuernavaca: UNAM, Centro Regional de Investigaciones Multidisciplinarias

VÁZQUEZ GARCIA, Verónica \& María Eugenia CHÁVEZ ARELLANO (2008): Género, sexualidad y poder: el chisme en la vida estudiantil de la Universidad Autónoma Chapingo, México, Estudios sobre las culturas contemporáneas, №. 27, 2008, paginas. $77-112$.

VÁZQUEZ GARCIA, Verónica and María Eugenia CHÁVEZ ARELLANO (2012): Gossip, sexuality and hegemonic masculinity, $R F R / D R F$, Volume 34, Nos 1/2, páginas 165 - 179. 